\title{
PENERAPAN MODEL PREDICT OBSERVE EXPLAIN BERBANTUAN MEDIA SCRAPBOOK UNTUK MENINGKATKAN KEMAMPUAN BERPIKIR KRITIS SISWA SD
}

\author{
Linda Ayu Kusumaningsih ${ }^{1, *}$, Fina Fakhriyah ${ }^{2)} \&$ Mila Roysa $^{3)}$ \\ 1), 2), 3) Program Studi PGSD, FKIP - Universitas Muria Kudus \\ E-mail: kusumalinda836@gmail.com
}

\begin{tabular}{|c|c|}
\hline ARTICLE INFO & ABSTRACT \\
\hline $\begin{array}{l}\text { Article history } \\
\text { Received: August 12, } 2020 \\
\text { Revised: August 13, } 2020 \\
\text { Accepted: August 14, } 2020 \\
\text { Keywords: } \\
\text { predict observe explain, } \\
\text { critical thingking }\end{array}$ & $\begin{array}{l}\text { The low ability of students' critical thinking due to the learning process does } \\
\text { not apply innovative models or media. The delivery of material in teaching } \\
\text { and learning activities is still dominated by teachers so that the opportunity } \\
\text { for students to express their opinions is still low. From these various problems, } \\
\text { the solution that can be given is to apply the Predict Observe Explain model } \\
\text { assisted by scrapbook media. This study aims to describe the increase in } \\
\text { critical thinking skills using the predict observe explain learning model } \\
\text { assisted by scrapbook media in class V SD } 1 \text { Jepang Kudus. This type of } \\
\text { research is classroom action research. This type of research is classroom } \\
\text { action research. This research consists of } 4 \text { stages namely planning, action, } \\
\text { observation, and reflection. The research was conducted in } 2 \text { cycles with } 2 \\
\text { meetings each cycle. The subjects of this study were } 27 \text { students of grade V SD } \\
1 \text { Jepang Kudus in the } 2019 / 2020 \text { school year. The results showed that } \\
\text { students' critical thinking skills in cycle } 1 \text { obtained classical completeness by } \\
63 \% \text { with the criteria needed guidance, while in cycle } 2 \text { they obtained classical } \\
\text { completeness by } 85 \% \text { with good criteria. }\end{array}$ \\
\hline
\end{tabular}

\section{A. PENDAHULUAN}

Perubahan yang terjadi dalam pendidikan selalu mengalami peningkatan yang disesuaikan dengan perkembangan zaman itu sendiri. Kurikulum yang diterapkan di Indonesia pada saat ini merupakan pembaharuan dari kurikulum sebelumnya yakni kurikulum KTSP 2006 menjadi Kurikulum 2013. Kurikulum 2013 menekankan pada pembelajaran tematik terpadu. Ardianti dkk, (2018:19) menyatakan bahwa, pembelajaran terpadu yang mengaitkan beberapa muatan mata pelajaran dalam satu tema. Kurikulum 2013 adalah salah satu strategi pemerintah dalam meningkatkan kualitas pendidikan di Indonesia, dengan ciri menekankan tiga aspek pendidikan yang berupa kognitif, afektif dan psikomotorik.

Aspek kognitif merupakan salah satu aspek penting dari tiga aspek yang harus dimiliki siswa dalam penerapan kurikulum 2013. Guru perlu memberikan penilaian yang proporsional dalam semua aspek, yakni meliputi aspek kognitif, afektif dan psikomotorik. Dari berbagai aspek tersebut, kemampuan berpikir kritis merupakan bagian dalam aspek kognitif yang harus 
diasah dan dikembangkan siswa. Johnson (2011:185) menyatakan bahwa berpikir kritis merupakan proses siswa dalam mengevaluasi bukti, berasumsi, logika, dan bahasa. Kemampuan berpikir kritis ini juga merupakan salah satu ciri utama kemampuan berpikir tingkat tinggi (Ratu \& Erfan, 2018; Erfan \& Ratu, 2018). Hal ini sering diidentikan dengan pengembangan pembelajaran kognitif sebagai pelaksana kurikulum 2013 sehingga dengan meningkatnya kemampuan berpikir kritis, siswa akan lebih cakap dalam menanggapi masalah dalam pembelajaran dan berbagai fenomena yang ada dalam kehidupannya sehari-hari.

Berdasarkan hasil observasi yang dilakukan peneliti di SD 1 Jepang, Kecamatan Mejobo, Kabupaten Kudus dengan guru kelas V pada 12 November 2019, yang diketahui bahwa di SD tersebut guru kesulitan dalam pemilihan media yang tepat untuk diajarkan, selain itu beliau juga tidak memiliki banyak waktu untuk membuat media sehingga guru jarang menggunakan media yang dapat menarik minat siswa dalam pembelajaran. Penyampaian materi guru masih mendominasi kegiatan belajar mengajar sehingga kesempatan siswa untuk mengungkapkan pendapat/ide/gagasan masih rendah. Selain itu guru terlihat belum mampu mengelola keaktifan siswa karena selama proses pembelajaran banyak menyampaikan teori dan tidak adanya proses membangun pengetahuan siswa sendiri dengan menanggapi masalahmasalah yang ada saat pembelajaran. Hal tersebut berdampak terhadap perkembangan kognitif siswa terutama pada kemampuan berpikir kritis siswa. Adanya proses menggali pengetahuan secara individu dapat melatih perkembangan kemampuan berpikir kritis siswa, dengan demikian siswa akan paham tentang materi yang dipelajarinya.

Hasil wawancara dengan beberapa siswa menunjukkan bahwa siswa terkadang masih belum memahami materi yang diajarkan, pertanyaan yang diajukan guru dirasa sulit dan proses pembelajaran jarang sekali menggunakan model pembelajaran dan media sehingga siswa tidak tertarik dengan materi yang diajarkan. Hal ini didukung pada hasil prasiklus menunjukkan bahwa kemampuan berpikir kritis siswa pada muatan IPA dan muatan Bahasa Indonesia yaitu dari 27 siswa hanya ada 10 siswa (37\%) yang sudah mencapai kriteria ketuntasan minimal dengan nilai minimal 70 dan 17 siswa (63\%) belum mencapai kriteria ketuntasan minimal dengan nilai minimal yang telah ditetapkan yaitu 70. Berdasarkan hasil tersebut menunjukkan bahwa secara klasikal kemampuan berpikir kritis siswa masih dalam kriteria rendah.

Berdasrkan permasalahan di atas perlu adanya solusi yang tepat dalam proses pembelajaran yang membuat siswa dapat meningkatkan kemampuan berpikir kritisnya. Penerapan model dan penggunaan media pembelajaran menjadi salah satu cara yang tepat untuk meningkatkan berpikir kritis siswa, khususnya pada muatan IPA dan Bahasa Indonesia. Adapun salah satu model pembelajaran yang dapat digunakan adalah model pembelajaran 
Predict Observe Explain (selanjutnya disebut POE). Sulistiyono dan Dewiyanti (2014:17) menyatakan bahwa model POE menggabungan antara keterampilan kognitif (pengetahuan), afektif (sikap), dan psikomotorik siswa dengan melakukan eksperimen.

Model pembelajaran predict observe explain merupakan model yang efisien untuk menciptakan berpikir kritis siswa, karena strategi dalam pembelajarannya memposisikan siswa untuk menyelesaikan permasalahan yang diajukan guru melalui beberapa tahapan yaitu memprediksi (predict), melakukan percobaan atau mengamati secara langsung (observe) dan menjelaskan hasil pengamatan (explain). Sebagaimana menurut Dalziel (2010:16) mengemukakan bahwa predict observe explain ada tiga tahap, tahap pertama yaitu predict (prediksi) dimana siswa diberi informasi awal mengenai suatu masalah kemudian siswa diminta untuk memprediksi atau membuat dugaan sementara terhadap hasil dan kemungkinan yang terjadi terhadap suatu masalah tersebut. Tahap kedua yaitu observe (mengamati), setelah membuat prediksi atau dugaan mengenai hasil dan kemungkinan yang terjadi, siswa membuktikan prediksinya melalui kegiatan percobaan atau praktikum kemudian mengamati apa yang terjadi terhadap suatu masalah yang diamatinya. Tahap yang ketiga yaitu explain (menjelaskan), setelah membuat prediksi dan melakukan pengamatan, siswa kemudian menjelaskan kesesuaian antara prediksi yang telah dibuatnya dengan hasil pengamatan yang telah dilakukannya dari tahap observasi

Proses pembelajaran akan lebih inovatif dan menyenangkan dengan adanya media pembelajaran yang tentunya akan mempermudah proses pembelajaran. Aqib (2016:50) mengungkapkan bahwa, media pembelajaran digunakan untuk menyampaikan pesan sehingga mempermudah siswa dalam proses belajar mengajar. Salah satu media yang peneliti gunakan untuk mendukung model POE yaitu media scrapbook. Media scrapbook digunakan untuk mempermudah guru dalam penyampaian materi, dengan media scrapbook tentunya siswa akan mudah memahami materi yang disampaikan.

Penelitian sebelumnya menyatakan bahwa, media scrapbook adalah media berupa tempelan gambar atau hiasan lain yang diaplikasikan di atas kertas (Sprachforum dalam Heryaneu, Amir dan Pepen 2015:4). Menurut Heryaneu, Amir dan Pepen (2015:4) menyatakan ada banyak manfaat yang didapatkan dari scrapbook, diantaranya membuat siswa lebih kreatif, dan sebagai sarana rekreasi yang menumbuhkan semangat siswa. Scrapbook ini dipilih peneliti sebagai pengganti media textbook yang digunakan siswa sehari-hari dalam pembelajaran dimana media scrapbook ini merupakan media yang kreatif dan menarik siswa karna di dalamnya materi dikemas dalam bentuk 3 dimensi yang akan membuat siswa penasaran dan 
menarik untuk dibaca. Adapun kelebihan dari media scrapbook yaitu scrapbook sifatnya kongkrit dan lebih realistis menunjukkan pokok permasalahan yang dibahas, scrapbook bentuknya tiga dimensi dan menarik, scrapbook dapat mengatasi keterbatasan pengamatan kita, dan bahan-bahan membuat scrapbook mudah didapat, tanpa menggunakan peralatan khusus.

Berdasarkan uraian tersebut, meaka peneliti melakukan tindakan dengan menerapkan model pembelajaran predict observe explain berbantuan media scrapbook pada tema 6 panas dan perpindahannya untuk meningkatkan kemampuan berpikir kritis siswa.

\section{B. METODE PENELITIAN}

Pendekatan penelitian yang digunakan adalah penelitian tindakan kelas yang terdiri dari 4 tahapan yaitu perencanaa (planning), tindakan (action), observasi (observation), dan refleksi (reflection). Penelitian ini dilaksanakan dalam 2 siklus, setiap siklus dilakukan dalam 2 kali pertemuan. Penelitian ini dilaksanakan pada siswa kelas V SD 1 Jepang semester II tahun ajaran 2019/2020 yang berjumlah 27 siswa. SD 1 Jepang beralamat di Jl. Suryo Kusumo No 1375 Ds. Jepang Mejobo Kudus.

Teknik pengumpulan data yang digunakan oleh peneliti yaitu tes, observasi, wawancara dan dokumentasi. Tes digunakan peneliti untuk mengukur kemampuan berpikir kritis siswa. observasi dilakukan oleh peneliti untuk mengamati aktivitas belajar siswa selama proses pembelajaran berlangsung. Wawancara dalam penelitian ini dilakukan kepada guru dan beberapa siswa kelas V SD 1 Jepang untuk memperoleh informasi tentang permasalahan yang ada dalam kegiatan proses pembelajaran, sehingga data tersebut dapat dijadikan dasar dalam melaksanakan penelitian. Penelitian ini menggunakan dokumentasi dengan menghasilkan dokumen berupa tulisan maupun gambar yang berkaitan dengan proses pembelajaran. Indikator keberhasilan pada penelitian ini yakni 1) kemampuan berpikir kritis siswa pada tema panas dan perpindahannya dapat dikatakan meningkat jika nilai yang diperoleh $\geq 70$ dengan ketuntasan klasikal 70\%. 2) aktivitas belajar siswa pada tema panas dan perpindahannya dapat dikatan meningkat jika nilai yang diperoleh $\geq 70$ dengan ketuntasan klasikal 70\%.

\section{HASIL DAN PEMBAHASAN}

Penelitian menggunakan model predict observe explain berbantuan media scrapbook dilaksanakan pada kelas V SD 1 Jepang Kecamatan Mejobo Kabupaten Kudus. Permasalahan yang ditemukan pada kelas V SD 1 Jepang yakni model dan media pembelajaran yang digunakan kurang inovatif. Guru cenderung menggunakan metode ceramah pada saat proses 
pembelajaran sehingga siswa menjadi mudah bosan dan kurang antusias dalam mengikuti pembelajaran. Rendahnya kemampuan berpikir kritis siswa dapat diketahui berdasarkan hasil tes prasiklus yang dilakukan pada 12 November 2019 pada siswa kelas V SD 1 Jepang pada tema 5 Ekosistem subtema 1 Komponen Ekosistem memperoleh hasil nilai tertinggi 80, nilai terendah 25 dengan jumlah siswa tuntas sebanyak 10 siswa, jumlah yang tidak tuntas sebanyak 17 siswa, ketuntasan klasikal 37\% dan nilai rata-rata klasikal 60,55 dengan kriteria kurang. Rendahnya kemampuan berpikir kritis siswa terjadi karena kurangnya antusias siswa dalam memperhatikan materi yang disampaikan guru dan kegiatan belajar mengajar yang masih satu arah.

Rendahnya kemampuan berpikir kritis siswa dapat ditingkatkan dengan menggunakan model predict observe explain berbantuan media scrapbook. Menurut Widyaningrum (2013:103) model pembelajaran predict observe explain dapat meningkatkan potensi siswa dalam memecahkan masalah melalui tahap prediksi, pengamatan dan penjelaskan. Warsono dan Hariyanto (2013: 93) struktur kognitif dan pemahaman peserta didik dapat ditingkatkan dengan interaksinya dengan teman sebaya dan guru melalui kegiatan prediksi, observasi dan menerangkan hasil pengamatan. Dapat disimpulkan bahwa Predict Observe Explain merupakan model pembelajaran yang menuntun siswa dalam memecahkan masalah melalui tiga tahapan yakni, prediksi atau dugaan sementara, observasi atau pengamatan dan menjelaskan hasil pengamatan.

Media scrapbook dapat meningkatkan kemampuan berpikir kritis siswa. Menurut Mahadzir and Phung (2013) scrapbook dapat menarik perhatian siswa dan meningkatkan kepuasan hasil pembelajaran. Mariani dan Kusumawardani (2014) untuk meningkatkan minat belajar siswa dapat menggunakan media scrapbook sebagai alternative pembelajaran. Dapat disimpulkan media scrapbook merupakan media unik dan kreatif yang dikemas dalam bentuk tiga dimensi untuk menarik perhatian siswa dan minat belajar siswa sehingga dapat meningkatkan kepuasan hasil pembelajaran.

Peneliti merencanakan kegiatan pembelajaran model predict observe explain berbantuan media scrapbook. Tindakan ini disesuaikan dengan jenis penelitian yang dilakukan yaitu Penelitian Tindakan Kelas dengan empat tahao yakni perencanaan, tindakan, pengamatan dan refleksi. Pada tahap pelaksaan diterapkan model predict observe explain berbantuan media scrapbook dengan langkah-langkah kegiatan sebagai berikut. (1) membuat prediksi atau dugaan sementara, (2) melakukan percobaan atau pengamatan, (3) menjelaskan keterkaitan antara dugaan sementara dengan hasil pengamatan. Untuk mengetahui hasil kemampuan 
berpikir kritis siswa peneliti menggunakan soal tes evaluasi yang disesuaikan dengan indikator kemampuan berpikir kritis siwa menurut Susanto (2016: 125-126) yakni, (1) memberikan penjelasan sederhana, (2) membangun keterampilan dasar, (3) menyimpulkan, (4) memberikan penjelasan lanjut, (5) mengatur strategi dan taktik.

Hasil penelitian yang diperoleh dari hasil pembelajaran tema 6 panas dan perpindahannya melalui model predict observe explain berbantuan media scrapbook. Hasil penelitian pada prasiklus, siklus I dan siklus II diperoleh sebagai berikut.

Tabel 1. Peningkatan Kemampuan berpikir kritis siswa Prasiklus, siklus I dan siklus II

\begin{tabular}{|c|c|c|c|c|c|c|c|}
\hline \multirow{2}{*}{ Nilai } & \multirow{2}{*}{ Keterangan } & \multicolumn{2}{|c|}{ Prasiklus } & \multicolumn{2}{|c|}{ Siklus I } & \multicolumn{2}{|c|}{ Siklus II } \\
\hline & & $\mathbf{F}$ & $\mathbf{P}(\%)$ & $\mathbf{F}$ & $\mathbf{P}(\%)$ & $\mathbf{F}$ & $\mathrm{P}(\%)$ \\
\hline$\geq 70$ & Tuntas & 17 & 37 & 10 & 63 & 23 & 85 \\
\hline$<70$ & $\begin{array}{l}\text { Tidak } \\
\text { Tuntas }\end{array}$ & 10 & 63 & 17 & 37 & 4 & 15 \\
\hline \multicolumn{2}{|c|}{ Jumlah } & 27 & 100 & 27 & 100 & 27 & 100 \\
\hline \multicolumn{2}{|c|}{ Rata-rata } & 60 & & 67 & & 80 & \\
\hline \multicolumn{2}{|c|}{ Minimum } & 25 & & 25 & & 50 & \\
\hline \multicolumn{2}{|c|}{ Maksimum } & 85 & & 85 & & 90 & \\
\hline
\end{tabular}

Sumber: Data Primer

Keterangan: $\mathrm{F}=$ Frekuensi

$\mathrm{P}=$ Persentase

Berdasarkan tabel 1 dapat dilihat bahwa hasil tes evaluasi siswa muatan Bahasa Indonesia dan IPA mengalami peningkatan pada setiap siklusnya. Penerapan model predict observe explain berbantuan media scrapbook terbukti sangat berpengaruh pada peningkatan kemampuan berpikir kritis siswa yang dapat dilihat dari kenaikan rata-rata dari pasiklus, siklus 1 dan siklus II. Peningkatan kemampuan berpikir kritis siswa dari hasil tes evaluasi yang disajikan dengan gambar sebagai berikut.

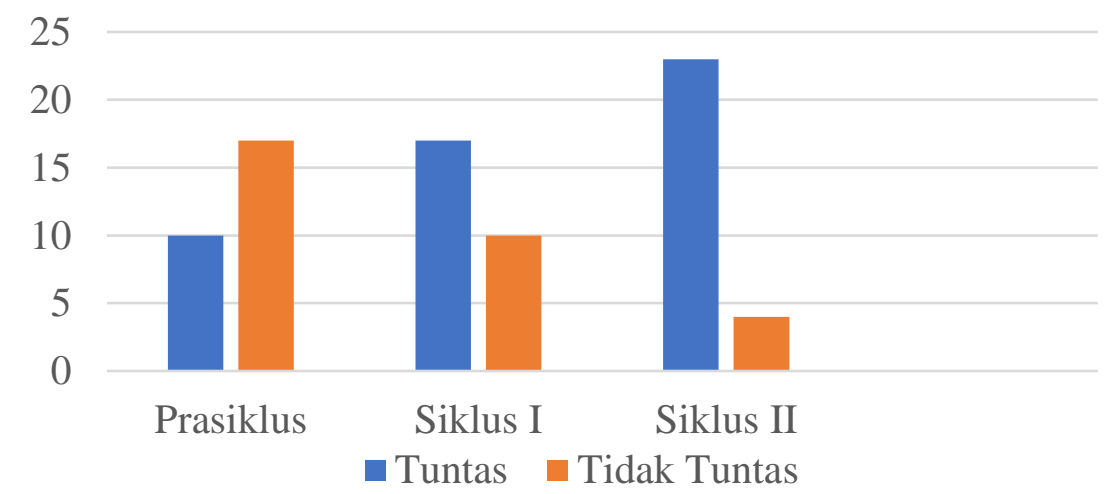

Gambar 1. Diagram Batang Perbandingan Hasil Tes Evaluasi Kemampuan Berpikir Kritis Siswa 
Berdasarkan gambar 1 hasil evaluasi tes akhir siklus 1 diperoleh hasil dengan nilai tertinggi 80 , nilai terendah 35, jumlah siswa tuntas sebanyak 17 siswa, jumlah siswa tidak tuntas sebanyak 10 siswa, ketuntasan klasikal sebesar 63\% dan nilai rata-rata 67 dengan kriteria kurang. Terjadi peningkatan kemampuan berpikir kritis siswa dari hasil tes prasiklus ke siklus I.

Hasil evaluasi tes akhir siklus II diperoleh hasil dengan nilai tertinggi 90, nilai terendah 50, jumlah siswa tuntas sebanyak 23 siswa, jumlah siswa tidak tuntas sebanyak 4 siswa, ketuntasan klasikal $85 \%$ dan niali rata-rata 77 dengan kriteria baik, terjadi peningkatan dari siklus I ke siklus II.

Tes evaluasi siklus II pada muatan Bahasa Indonesia dan IPA sudah mencapai target ketuntasan klasikal hasil tes evaluasi kemampuan berpikir kritis siswa yaitu 70\%, karena ketuntasan klasikal pada siklus II memperoleh $85 \%$. Presentase yang diperoleh sudah memenuhi batas minimal indikator keberhasul yang sudah ditentukan. Hal tersebut membuktikan penerapan model pembelajaran predict observe explain berbantuan media scrapbook dapat meningkatkan kemampuan berpikir kritis siswa.

\section{PENUTUP}

Berdasarkan hasil penelitian dan pembahasan dapat disimpulkan bahwa peningkatan kemampuan berpikir kritis siswa kelas V SD 1 Jepang Kecamatan Mejobo Kabupaten Kudus dapat diupayakan melalui model pembelajaran predict observe explain berbantuan media scrapbook. Hal ini Nampak pada perbandingan ketuntasan klasikal hasil tes evaluasi diperoleh data prasiklus 37\%, siklus I 63\% dan siklus II 85\%.

Berdasarkan hasil penelitian ini, disarankan kepada para guru mengimplementasikan model pembelajaran predict observe explain berbantuan media scrapbook dalam pembelajaran untuk melatih siswa memecahkan permasalahan dalam proses pembelajaran dengan suasana belajar yang menyenangkan.

\section{DAFTAR PUSTAKA}

Aqib, Zaenal. 2016. Model-Model Media, dan Strategi Pembelajaran Konstekstual. Bandung: Yrama Widya.

Ardianti, Sekar Dwi, Ulya Himmatul, Ismaya, Erik Aditia. 2018. PAKEM Dalam Kurikulum 2013. Kudus: Badan Penerbit Universitas Muria Kudus.

Dalziel, James. Practical eTeaching Strategies for Predict-Observe-Explain, Problem-Based Learning and Role Play. Australia: LAMS International. 
Erfan, M., \& Ratu, T. (2018). Pencapaian HOTS (Higher Order Thinking Skills) Mahasiswa Program Studi Pendidikan Fisika FKIP Universitas Samawa. Jurnal Pendidikan Fisika Dan Teknologi, 4(2), 208. https://doi.org/10.29303/jpft.v4i2.831

Haryaneu, Y. 2014. Efektivitas Penggunaan Media Scrapbook untuk Meningkatkan Kemampuan Menulis Karangan Deskripsi.

Johnson, E.B. 2011. Contextual Teaching Learning: Menjadikan Kegiatan Belajar-Mengajar Mengasyikkan dan Bermakna. Bandung: Mizan Media Utama.

Mahadzir, N., \& Phung, L. F. (2013). The use of augmented reality pop-up book to increase motivation ini English language learning for national primary school. Journal of Research \& Method in Education. 1(1), 26-38.

Mariani, S. W., \& Kusumawardani, E. (2014). The effectiveness of learning by PBL assisted mathematics pop up book against the spatial ability in grade VIII on geometry subject matter. International Journal of Education and Research, 2(2), 531-548.

Ratu, T., \& Erfan, M. (2018). Meningkatkan keterampilan procedural dan keterampilan berpikir tinggi mahasiswa melalui model pemecahan masalah pada perkuliahan elektronika dasar Improving Student's Procedural Skills and Higher Order Thinking Skills of Students Through Problem-Solving. Jurnal Pendidikan Fisika Dan Keilmuan, 4(1), 30-35. https://doi.org/10.2572/jpfk.v4i1.2017

Sulistiyono dan Dewiyanti, F. 2014. Penerapan Model Prediction, Observation, Explanation (POE) untuk Meningkatkan Hasil Belajar Fisika Siswa Kelas X1 SMA Negeri 8 Lubuklinggau Tahun Pelajaran 2012/2013. Jurnal Perspektif Pendidikan, 8 (1), Hlm. 16-21.

Susanto, Ahmad. 2016. Teori Belajar dan Pembelajaran di Sekolah Dasar. Jakarta: Prenadamedia Group.

Warsono dan Hariyanto. 2013. Pembelajaran Aktif Teori dan Asesmen. Bandung: PT Remaja Rosdakarya.

Widyaningrum, R. 2013. Pengembangan Modul Berorientasi POE (Predict, Observe, Explain) Berwawasan Lingkungan pada Materi Pencemaran untuk Meningkatkan Hasil Belajar Siswa. Jurnal Bioedukasi Universitas Sebelas Maret. Vol 6. Hlm. 100-117. 